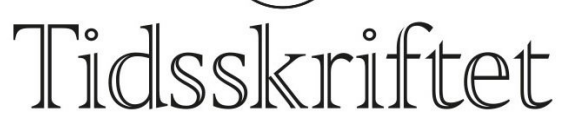

DEN NORSKE LEGEFORENING

\title{
Klamydiaepidemien som viste seg å være feilregistreringer
}

DEBATT

\section{BJØRG ELISE TØNNESEN DYSTHE}

E-post: bdy@baerum.kommune.no

Bjørg Elise Tønnesen Dysthe (f. 1957) er spesialist i samfunnsmedisin og smittevernoverlege i Bærum kommune.

Forfatter har fylt ut ICMJE-skjemaet og oppgir følgende interessekonflikter: Hun har mottatt tilskudd fra Helsedirektoratet/Fylkesmannen i Oslo og Akershus, og stipend fra Allmennlegeforeningens forskningsfond.

\section{GJERTRUD LøDØEN}

Gjertrud Lødøen (f. 1956) er spesialist i samfunnsmedisin og assisterende kommuneoverlege i Bærum kommune.

Forfatter har fylt ut ICMJE-skjemaet og oppgir følgende interessekonflikter: Hun har mottatt tilskudd fra Helsedirektoratet/Fylkesmannen i Oslo og Akershus, og stipend fra Allmennlegeforeningens forskningsfond.

\section{MARIA ROMØREN}

Maria Romøren (f. 1974) er allmennlege og postdoktor ved Institutt for helse og samfunn, Universitetet i Oslo.

Forfatter har fylt ut ICMJE-skjemaet og oppgir ingen interessekonflikter.

\section{MORTEN LINDBAEK}

Morten Lindbæk (f. 1950) er professor i allmennmedisin Institutt for Helse og Samfunn UiO, leder Antibiotikasenteret for primærmedisin (ASP).fastlege

Forfatter har fylt ut ICMJE-skjemaet og oppgir ingen interessekonflikter.

\section{Klamydia er utbredt blant ungdom. Lokalt smittevernarbeid, evaluering av tiltak og oppfølging av lokal statistikk er vesentlig, noe denne historien fra Bærum kommune illustrerer.}

Genital klamydia (Chlamydia trachomatis) er den mest utbredte seksuelt overførbare bakterielle infeksjonen i Norge (1). Utbredelsen er spesielt høy blant ungdom under 25 år (2). Bærum kommune opplevde fra 2005 til 2014 en tredobling av positive genital klamydiaprøver registrert i Folkehelseinstituttets meldesystem for smittsomme sykdommer (MSIS). Dette var unikt for Bærum og medførte flere medieoppslag: «Rekordmange tilfeller av klamydia: - Unge dropper kondom» (3) og «Klamydia-eksplosjon blant Bærums-ungdom» (4). I perioden hadde kommunen gjentatte informasjonskampanjer om klamydia rettet mot ungdom. Til tross for disse kampanjene fortsatte økningen. Kommuneoverlegene undersøkte flere faktorer som prevensjonsvaner, seksuell debutalder og ikke minst 
testatferd. Vår hypotese var at ungdom i Bærum testet seg mer for klamydia som følge av våre informasjonskampanjer og at dette kunne forklare det store antallet positive prøver.

Ved nærmere undersøkelse viste det seg imidlertid at $ø$ kningen av klamydia ikke var reell. $\emptyset$ kningen var knyttet til registreringsrutinene fra et av laboratoriene. Folkehelseinstituttet stiller krav om at laboratorier som innrapporterer meldepliktige smittsomme sykdommer samtidig oppgir pasientens hjemstedskommune. Praksis ved Fürst Medisinsk Laboratorium var at prøver som manglet kommuneopplysninger ble registrert på kommunen med det største NAV-kontoret i fylket. I Akershus' tilfelle var dette Bærum. Økning i bruk av laboratorietjenester hos Fürst i Akershus i perioden 2005-14 førte dermed til en uforholdsmessig økning i antallet klamydiatilfeller tilskrevet Bærum kommune. Så mye som halvparten av de positive prøvene registrert i Bærum i 2014 kunne ikke med sikkerhet knyttes til personer bosatt i kommunen. Den store klamydiaepidemien i Bærum var med andre ord neppe reell.

Etter smittevernloven § 7-2 skal kommunelegen «ha løpende oversikt over de infeksjonsepidemiologiske forholdene i kommunen». Validering av innrapporterte prøver viste at den tilsynelatende høye forekomsten skyldtes feilrapportering. Denne saken illustrerer betydningen av kommunalt smittevernarbeid og epidemiologisk overvåkning. Saken illustrerer også betydningen av å sjekke uventede funn før man går videre med tiltak.

LITTERATUR:

1. MSIS-statistikk på klamydia 2005-14. www.msis.no (17.9.2015).

2. Folkehelseinstituttet. http://www.fhi.no/publikasjoner-og-haandboker/smittevernboka (25.1.2018).

3. Bjørnstad A, Blåsmo T. Rekordmange tilfeller av klamydia: - Unge dropper kondom. Budstikka

23.9.2013.

https://www.budstikka.no/nyheter/nyheter/rekordmange-tilfeller-av-klamydia-unge-dropper-kondom /s/2-2.310-1.8081157 (25.1.2018).

4. Kirkebøen S. Klamydia-eksplosjon blant Bærums-ungdom. Aftenposten 24.11.2014. https://www.aftenposten.no/osloby/i/1keaM/Klamydia-eksplosjon-blant-Barums-ungdom (25.1.2018).

Publisert: 19. februar 2018. Tidsskr Nor Legeforen. DOI: 10.4045/tidsskr.17.0965

Mottatt 6.11.2017, første revisjon innsendt 22.1.2018, godkjent 25.1.2018.

(C) Tidsskrift for Den norske legeforening 2020. Lastet ned fra tidsskriftet.no 